ORIGINAL ARTICLE

\title{
Outcome of acute bacterial meningitis among children in Tertiary care hospital.
}

\author{
Zunaira Javed ${ }^{1}$, Syed Usama Masood ${ }^{2}$, Javaid Laal ${ }^{3}$
}

Article Citation: Javed Z, Masood SU, Laal J. Outcome of acute bacterial meningitis among children in Tertiary care hospital. Professional Med J 2022; 29(2):167-171. https://doi.org/10.29309/TPMJ/2022.29.02.6533

\begin{abstract}
Objective: To determine the frequency of Hemophilus Influenzae type b, streptococcus pneumonia and Niesseria Meningitidis and outcome in culture proven meningitis in children 6 months to 24 months of age admitted in children ward. Study Design: Cross Sectional Analytical study. Setting: Pediatric Medical Unit of Bahawal Victoria Hospital, Bahawalpur. Period: January 2019 to December 2019. Material \& Methods: A total of 220 children of either sex with culture proven meningitis, aged 6 months to 24 months, were included in the study. Demographic characteristics, duration of fever, history of seizures, weight of child, vaccination status and bacteria isolated from Cerebrospinal Spinal Fluid (CSF) and outcome were analyzed. Confidentiality of data was maintained and it was assured that no harm to the participants will be done. The outcome in the form of mortality was noted during the first 10 days of hospital stay. There was no conflict of interest among the authors and study was self-funded. Results: Amongst a total of 220 children, $123(55.9 \%)$ were male. There were $130(59.1 \%)$ children who were less than or equal to 1 year of age. There were $154(70.0 \%)$ children who were having a weight of 7 to $10 \mathrm{~kg}$. Vaccination status showed that, $111(50.5 \%)$ were fully vaccinated, $59(26.8 \%)$ partially vaccinated and $50(22.7 \%)$ not vaccinated. Duration of fever revealed that, $141(64.1 \%)$ had fever for more than 5 days. There were 139 (63.2\%) children who had a history of seizures. Streptococcus pneumonia was the commonest bacteria found in $110(50 \%)$ children followed by Neisseria meningitides $53(24.1 \%)$, H. Influenza $37(16.8 \%)$. Overall mortality was noted in $34(15.5 \%)$ children. Conclusion: In children with bacterial meningitis, mortality was high and most common bacteria were found to be S.pneumoniae followed by H.influenzae.
\end{abstract}

Key words: Bacterial Meningitis, H. Influenza, Mortality, Streptococcus Pneumoniae.

\section{INTRODUCTION}

Bacterial meningitis in children is a life-threatening illness that results from bacterial infection of the meninges and leaves some survivors with significant sequelae. More than two third cases of meningitis occur in the $1^{\text {st }}$ and $2^{\text {nd }}$ years of life, owing to decreased immunity and high vascularity of the brain. ${ }^{1}$

The three most common bacteria among the age group of 2 months to 24 months in the descending order of frequency are Hemophilus influenza type b, streptococcus pneumonia and Neisseria meningitides before the introduction of conjugated Hemophilus influenza and pneumococcal vaccination in routine immunization program. The introduction of these vaccinations not only reduced the mortality but also changed the etiology of bacterial meningitis. ${ }^{2}$ So, now in vaccinated children, the most common organism in the descending order of frequency are streptococcus pneumonia, neisseria meningitides while the incidence of meningitis due to hemophilus influenza type $b$ has dramatically decreased. ${ }^{3}$ The study done by Chinchankar $\mathrm{N}$ et al in $2002^{4}$ before the introduction of hemophilus influenza type b, streptococcus pneumonia routine vaccination showed streptococcus pneumonia 39\% hemophilus influenza type b $26 \%$ and others $35 \%$, and mortality in $31.5 \%$ of cases. The study done by Levy $\mathrm{C}$ et al in $2014^{5}$ showed mortality $10.6 \%$ after the introduction of routine vaccination. The study done by Kuti $\mathrm{BP}$ et al in $2015^{6}$ in Nigeria, where vaccination is very poor showed commonest bacteria $\mathrm{H}$. influenza type $\mathrm{b}$ and S. pneumonia while mortality was $27.2 \%$. The
1. MBBS, FCPS, Senior Registrar Pediatrics, Bahawal Victoria Hospital, Bahawalpur.

2. MBBS, FCPS, Clinical Fellow Pediatric Nephrology, Children Hospital and Institute of Child Health Multan.

3. MBBS, FCPS, Medical Officer Pediatrics, Bahawal Victoria Hospital, Bahawalpur.

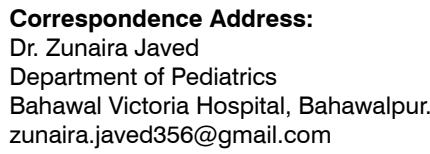

Correspondence Address:

Dr. Zunaira Javed

Department of Pediatrics

Bahawal Victoria Hospital, Bahawalpur. zunaira.javed356@gmail.com

Article received on:

$13 / 04 / 2021$

Accepted for publication:

$30 / 06 / 2021$ 
studies done in various parts of Pakistan showed highly variable mortality ranging from $1.67-34 \% .{ }^{7-}$ 10

The routine vaccination in Pakistan especially in our area is very poor and meningitis is a common problem with a highly variable mortality in other parts of Pakistan with no local data is available. Moreover, the search done on PUBMED, PAKMEDINET and MEDLIP showed that very little national but no local data available about the etiology of bacterial meningitis below the 2 years of age after introduction of $\mathrm{H}$. influenza type $\mathrm{b}$ and S. pneumonia. So, this study was planned to determine the frequency of hemophilus influenza type b, streptococcus pneumonia and neisseria meningitidis and outcome in culture proven meningitis in children 6 months to 24 months. It was planned to help us in decreasing the morbidity and mortality due to the meningitis in the community.

The objective of the study was to determine the frequency of hemophilus influenza type b, streptococcus pneumonia and Neisseria meningitides, and outcome in culture proven meningitis among children between 6 months to 24 months admitted in pediatric ward.

\section{MATERIAL \& METHODS}

It was cross sectional analytic study conducted in pediatric unit of Bahawal Victoria Hospital, Bahawalpur from January 2019 to December 2019 after taking ethical approval from Institutional ethical review committee (1049/DME/QAMC Bahawalpur). Sample size calculated for the study at $17.24 \%$ anticipated population proportion, 5\% margin of error and $95 \%$ level of confidence was 220. Children of either gender between 6 months to 24 months of age admitted in children ward with culture proven meningitis were included in the study after taking informed written consent from the parents or guardian through non probability consecutive sampling method. Children with meningitis following head injury, meningocele or meningomyelocele, ventriculo-peritoneal shunt and with unknown vaccination status were excluded.
The outcome was measured in terms of death (absence of spontaneous or induced movements of body with no respiration and straight line on electrocardiogram) during first ten days of hospital stay. Demographic and clinical data was collected through specifically designed, pretested proforma. Demographic and clinical data included name, age, gender, duration of fever $\left(>38^{\circ} \mathrm{C}\right)$, history of seizure/seizures developing during hospital stay, weight of child, vaccination status and bacteria isolated from cerebrospinal fluid (CSF) and outcome of the patient. All cases were given intravenous (IV) antibiotics (vancomycin 60mg/kg/day given every 8 hourly and Ceftriaxone $100 \mathrm{mg} / \mathrm{kg} /$ day given 12 hourly) for a period of 10 days. Injection dexamethasone was also given IV $0.2 \mathrm{mg} / \mathrm{kg} /$ dose 8 hourly for 2 days starting with the $1^{\text {st }}$ dose of antibiotics. The outcome in the form of mortality was noted during the first 10 days of hospital stay. SPSS version 22.0 was used for statistical data analysis. Mean and standard deviations for age, weight and duration of fever were calculated. The frequency and percentage were calculated for hemophilus influenza type b, streptococcus pneumonia and Neisseria meningitides, presence of seizures, vaccination status and mortality. Effect modifiers like age, weight, duration of fever, presence of seizures an vaccination status were controlled through stratification. Post stratification chi square test was applied and $p$ value less than 0.05 was taken as significant.

\section{RESULTS}

Amongst a total of 220 children, 135 (61.4\%) were male and 85 (38.6\%) female. There were 130 $(59.1 \%)$ children who were less than or equal to 1 year of age while 90 (40.9\%) over 1 year. Mean age amongst children was 13.38 months with a standard deviation of \pm 5.9 months. There were $62(28.2 \%)$ children who were having weight of less than or equal to $6 \mathrm{~kg}, 149(67.7 \%)$ having 7 to $10 \mathrm{~kg}$ and 9 (4.1\%) over $10 \mathrm{~kg}$. Mean Weight was $7.26 \mathrm{~kg}$ with a standard deviation of $\pm 1.8 \mathrm{~kg}$. As far as vaccination status was concerned, 112 (50.9\%) were fully vaccinated, 58 (26.4\%) partially vaccinated and $50(22.7 \%)$ not vaccinated.

Duration of fever showed that, 79 (35.9\%) having 
fever from five or less days whereas other 141 $(64.1 \%)$ had fever for more than 5 days. There were $139(63.2 \%)$ children who had a history of seizures.

Streptococcus pneumonia was the commonest bacteria found in $110(50 \%)$ children followed by Neisseria meningitides $53(24.1 \%), \mathrm{H}$. Influenza $37(16.8 \%)$ whereas $20(9.1 \%)$ children were found having other bacteria. Overall mortality was noted in 34 (15.5\%) children.

When different variables were compared in terms of outcome, $p$ value turned out to be > 0.05 that proved statistical insignificance for weight of children, history of fever and history of seizures in terms of outcome in children with bacterial meningitis while age $(p=0.020)$, gender $(p=0.008)$ and vaccination status $(p<0.01)$ of the children was significantly related with the outcome.

\begin{tabular}{|c|c|c|}
\hline Variables & Frequency & Percentage \\
\hline $\begin{array}{l}\text { Age } \\
\leq 1 \text { year } \\
>1 \text { year }\end{array}$ & $\begin{array}{l}130 \\
090\end{array}$ & $\begin{array}{l}59.1 \% \\
40.9 \%\end{array}$ \\
\hline $\begin{array}{l}\text { Gender } \\
\text { Male } \\
\text { Female }\end{array}$ & $\begin{array}{l}135 \\
085\end{array}$ & $\begin{array}{l}61.4 \% \\
38.6 \%\end{array}$ \\
\hline $\begin{array}{l}\text { Weight } \\
\leq 6 \mathrm{~kg} \\
7-10 \mathrm{Kg} \\
>10 \mathrm{~kg}\end{array}$ & $\begin{array}{c}062 \\
149 \\
09\end{array}$ & $\begin{array}{l}28.2 \% \\
67.7 \% \\
04.1 \%\end{array}$ \\
\hline $\begin{array}{l}\text { Vaccination Status } \\
\text { Fully vaccinated } \\
\text { Partially vaccinated } \\
\text { Not vaccinated }\end{array}$ & $\begin{array}{l}112 \\
058 \\
050\end{array}$ & $\begin{array}{l}50.9 \% \\
26.4 \% \\
22.7 \%\end{array}$ \\
\hline $\begin{array}{l}\text { Duration of fever } \\
\leq 5 \text { days } \\
>5 \text { days }\end{array}$ & $\begin{array}{l}079 \\
141\end{array}$ & $\begin{array}{l}35.9 \% \\
64.1 \%\end{array}$ \\
\hline $\begin{array}{l}\text { History of seizures } \\
\text { Yes } \\
\text { No }\end{array}$ & $\begin{array}{l}139 \\
081\end{array}$ & $\begin{array}{l}63.2 \% \\
36.8 \%\end{array}$ \\
\hline
\end{tabular}

Table-I. Characteristics of the children with bacterial meningitis. $(n=220)$

\begin{tabular}{|l|c|}
\hline \multicolumn{1}{|c|}{ Microorganism } & Number (\%) \\
\hline H. Influenza & $37(16.8 \%)$ \\
\hline Streptococcus Pneumonia & $110(50 \%)$ \\
\hline Neisseria Meningitidis & $53(24.1 \%)$ \\
\hline Others & $20(9.1 \%)$ \\
\hline Total & $220(100 \%)$ \\
\hline \multicolumn{2}{|c|}{ Table-II. Bacteria involved in culture proven } \\
meningitis. (n=220)
\end{tabular}

\begin{tabular}{|l|c|c|}
\hline \multicolumn{2}{|c|}{ Mortality } & \multicolumn{3}{c|}{ Number (\%) } \\
\hline Yes & \multicolumn{3}{|c|}{$186(15.5 \%)$} \\
\hline No & \multicolumn{3}{|c|}{$220(100 \%)$} \\
\hline Total \\
\multicolumn{1}{|c|}{ Table-III. Mortality amongst children with culture } \\
proven bacterial meningitis.
\end{tabular}

Table-IV. Characteristics of the children with bacterial meningitis and mortality.

\begin{tabular}{|l|c|c|c|}
\hline \multicolumn{1}{|c|}{$\begin{array}{c}\text { Bacteria } \\
\text { Involved }\end{array}$} & \multicolumn{2}{c|}{ Mortality } & \multicolumn{1}{c|}{ Total } \\
\hline H. Influenza & $8(23.5 \%)$ & $29(15.6 \%)$ & $37(16.8 \%)$ \\
\hline $\begin{array}{l}\text { Streptococcus } \\
\text { Penumonia }\end{array}$ & $19(55.9 \%)$ & $91(48.9 \%)$ & $\begin{array}{c}110 \\
(50.0 \%)\end{array}$ \\
\hline $\begin{array}{l}\text { Neisserria } \\
\text { Meningitidis }\end{array}$ & $4(11.8 \%)$ & $49(26.3 \%)$ & $53(24.1 \%)$ \\
\hline Others & $3(8.8 \%)$ & $17(9.1 \%)$ & $20(9.1 \%)$ \\
\hline Total & $34(15.5 \%)$ & $186(84.5 \%)$ & $220(100 \%)$ \\
\hline
\end{tabular}

Table-V. Mortality and bacteria involved amongst children.

Chi square $=3.895 p$ value $=0.273$

\section{DISCUSSION}

Bacterial meningitis contributes considerably to children morbidity and mortality. ${ }^{11}$ In the present study, more male children (55.9\%) got enrolled as compared to females. This has been found earlier as well that males are affected more as compared 
to females. ${ }^{12}$

Age has been an important contributing factor in terms of contribution to incidence and mortality related to bacterial meningitis. The incidence of bacterial meningitis is very age specific as it is found more among newborn infants and elderly. The attack rates for newborn are around 400 cases per 100,000 while this is reduced to only 1-2 per 100,000 in adults which is consistent with our findings in which about $60 \%$ children were having age less than or equal to 1 year. ${ }^{13}$

In the present study more than two third children had weight between $7-10 \mathrm{~kg}$ and mortality was also high in these children which is similar with the findings of literature in which high mortality rates were noted among underweight children. ${ }^{14}$

Vaccination status in this study showed that about half of the children enrolled in the study were either partially vaccinated or not vaccinated at all and most common bacteria was found as streptococcus pneumonia Overall mortality was noted in $15.5 \%$ children which are quite similar to findings of Kakkar et al in which S. pneumoniae as the commonest cause of mortality in bacterial meningitis followed by $\mathrm{H}$.influenzae. ${ }^{9}$ Duration of illness before admission to hospital appear to be a contributing factor to mortality in bacterial meningitis ${ }^{9}$ which is inconsistent with our findings in which duration of fever was not significantly associated with mortality. This may be due to easy availability of child specialists in the primary and secondary healthcare level and referral of only complicated cases to specialized healthcare hospitals. It has been revealed in the past that prolonged duration of illness prior to the admission lead to delay in diagnosis an initiation of effective and adequate management of the disease. Enhancing routine immunization services can go a long way toward preventing meningitis. The Hib, measles, mumps, polio, and pneumococcal vaccines can protect against meningitis. Children and adults which are taking care of child should wash their hands well and often, particularly before eating and after using the bathroom. If child has been in close contact with someone who has meningitis than it will be beneficial to visit child specialist as early as possible. ${ }^{16}$

\section{CONCLUSION}

In children with bacterial meningitis, mortality was high and most common bacteria were found to be s.pneumoniae followed by h.influenzae.

\section{Copyright $@ 30$ June, 2021.}

\section{REFERENCES}

1. Luksic I, Mulic R, Falconer R, Orban M, Sidhu S, Rudan I. Estimating Global and regional morbidity from acute bacterial meningitis in children: Assessment of the evidence. Croat Med J. 2013; 54(6):510-8.

2. Davis S, Feikin D, Johnson HL. The effect of Haemophilus influenza type $B$ and pneumococcal conjugate vaccines on childhood meningitis mortality: A systematic review. BMC Public Health. 2013; 13 Suppl 3:s21.

3. Brouwer MC, Tunkel AR, Van de Beek D. Epidemiology, diagnosis, and antimicrobial treatment of acute bacterial meningitis. Clin Microbiol Rev. 2010; 23(3):467-92.

4. Chinchankar N, Mane M, Bhave S, Bapat S, Bavdekar $A$, Pandit A, et al. Diagnosis and outcome of acute bacterial meningitis in early childhood. Indian Pediatr. 2002; 39(10):914-21.

5. Levy C, Varon E, Picard C, Bechet S, Martinot A, Bonacorsi $S$, et al. Trends of pneumococcal meningitis in children after introduction of the 13-valent peneumococcal conjugate vaccine in France. Pediatr Infect Dis J. 2014; 33(12):1216-21.

6. Kuti BP, Bello EO, Jegede TO, Olubosede O. Epidemiological, clinical and prognostic profile of childhood acute bacterial meningitis in a resource poor setting. J Neurosci Rural Pract. 2015; 6(4):549-57.

7. Naz S, Mushtaq A, Khan MZ, Bari A, Ahmad TM. Spectrum of acute complications and mortality in bacterial meningitis. Pak Pediatr 2012; 36(3):132-6.

8. Asghar RM, Ghani Z, Sharif M. Causative organisms, clinical course and complications of pyogenic meningitis in children. J Rawal Med Coll. 2008; 12(2):88-91.

9. Kakar BA, Ahmed S, Kakar RM. Mortality and morbidity of 118 cases of acute pyogenic meningitis in paediatrics age group. Ann King Edward Med Uni. 2006; 12(2):204-7. 
10. KhowajaAR, Mohiuddin S, Cohen AL, Khalid A, Mehmood $U$, Naqvi F, et al. Mortality and neurodevelopmental outcomes of acute bacterial meningitis in children aged <5 years in Pakistan. J Pediatr. 2013; 163(1 Supp):S86-S91.

11. Tsolenyanu E, Bancroft RE, Sesay AK, Senghore M, Fiawoo M, Akolly D, Godonou MA, Tsogbale N, Tigossou SD, Tientcheu L, Dagnra A. Etiology of pediatric bacterial meningitis pre-and post-PCV13 introduction among children under 5 years old in Lomé, Togo. Clinical Infectious Diseases. 2019 Sep 5; 69(Supplement_2):S97-104.

12. CDC. Centers for diseases control and prevention (2011). Empidemiology of meningitis caused by neisseria meningitides, streptococcus pneumonia, and haemophilus influenza. Available at: http://www. cdc.gov/meningitis/lab-manual/chpt02-epi.html.
13. Loring KE. CNS infections. In: Tintinalli JE, Kelen GD, Stapczynski JS (Eds.). Emergency medicine: A comprehensive study guide. $6^{\text {th }}$ edition. McGraw-Hill, 2004, New York. Pp.1431-7.

14. Chang CJ, Chang WN, Huang LT, et al. Bacterial meningitis in infants: The epidemiology, clinical features, and prognostic factors. Brain Dev 2004; 26 : 168-75.

15. Kim KS. Acute bacterial meningitis in infants and children. The lancet infectious diseases. 2010 Jan 1; 10(1):32-42.

16. Guo LY, Li YJ, Liu LL, Wu HL, Zhou JL, Zhang Y, Feng WY, Zhu L, Hu B, Hu HL, Chen TM. Detection of pediatric bacterial meningitis pathogens from cerebrospinal fluid by next-generation sequencing technology. Journal of Infection. 2019 Apr 1; 78(4):323-37.

\begin{tabular}{|c|l|l|l|}
\hline \multicolumn{3}{|c|}{ AUTHORSHIP AND CONTRIBUTION DECLARATION } \\
\hline No. & \multicolumn{1}{|c|}{ Author(s) Full Name } & Contribution to the paper & Author(s) Signature \\
\hline 1 & Zunaira Javed & Manuscript writing. \\
\hline 2 & Syed Usama Masood & Data analysis. \\
\hline 3 & Javaid Laal & Data collection. & \\
\hline
\end{tabular}

